2) читання речень-прикладів, зміст яких відповідає темі, що вивчається; 3) складання речень шляхом розташування слів в правильному порядку.

Усі ці дії виконуються за допомогою таких технічних засобів, як таблиця неправильних дієслів, картки 3 граматичними структурами. Перевіряються знання граматики, що вивчається, шляхом перекладу речень з іноземної мови на рідну та з рідної на іноземну.

Отже, окреслені нами етапи дослідно-експериментального навчання учнів старшої школи та відповідна система вправ сприяють формуванню лінгвосоціокультурної компетенції учнів старшої школи.

\title{
ПЕРСПЕКТИВИ ВИКОРИСТАННЯ ХМАРНИХ ТЕХНОЛОГІЙ У НАВЧАЛЬНОМУ ПРОЦЕСІ ЗАГАЛЬНООСВІТНІХ НАВЧАЛЬНИХ ЗАКЛАДІВ УКРАЇНИ
}

Вакалюк Т. А., Поліщук В. В. Перспективи використання хмарних технологій у навчальному процесі загальноосвітніх навчальних закладів України.

У статті на основі аналізу наукової літератури наведені безумовні перспективи використання хмарних технологій у загальноосвітніх навчальних закладах України. Проаналізовано перспективи використання таких хмарних сервісів, як Office 365, Google Apps, Prezi. Наведено приклади їх використання в навчальному процесі шкіл України. 3'ясовано, що хмарні технології з легкістю розв'язують проблему навчальних закладів, яка полягає в неможливості своєчасного оновлення програмного та апаратного забезпечення.

Ключові слова: новітні технології, інформаційно-комунікаційні технології, хмарні технології, хмарні сервіси, навчальний процес.

Вакалюк Т. А., Полищук В. В. Перспективы использования облачных технологий в учебном процессе общеобразовательных учебных заведений Украины.

В статье на основе анализа научной литературы приведены безусловные перспективы использования облачных технологий в общеобразовательных учебных заведениях Украины. Проанализированы перспективы использования таких облачных сервисов, как Office 365 Google Apps, Prezi. Приведены примеры их использования в учебном процессе школ Украины. Установлено, что облачные технологии с легкостью решают проблему учебных заведений, которая заключается в невозможности своевременного обновления программного и аппаратного обеспечения.

Ключевые слова: новейшие технологии, информационно-коммуникационные технологии, облачные технологии, облачные сервисы, учебный процесс.

Vakalyuk T. A., Polishchuk V. V. Prospects of cloud technologies use in the training process of comprehensive educational institutions of Ukraine.

On the basis of analysis of scientific literature the prospects of cloud technologies use in comprehensive educational institutions of Ukraine are concidered. The prospects of cloud services such as Office 365, Google Apps, Prezi are analyzed. Examples of their use in training process of comprehensive educational institutions are given. It is analysed that cloud technologies solve the problem of educational institutions to update software and hardware timely.

Key words: new technologies, information and communication technologies, cloud 
technologies, cloud services, training process.

У наш час спостерігається стрімкий розвиток інформаційних технологій не лише в нашій країні, але й у світі загалом. Суспільство вже звикло до зручності використання комп’ютерних технологій у різних сферах людської діяльності, зокрема, і в навчальному процесі. Кожен учитель загальноосвітнього навчального закладу (ЗН3) намагається вдосконалити навчальний процес та урізноманітнити його використанням на уроках комп’ютерної техніки. За допомогою новітніх технологій учителю зручніше подати новий матеріал, а дітям легше його сприйняти. Сучасні діти вперше зустрічаються з комп’ютером у досить ранньому віці, тому такі нововведення для них є досить зручними.

Проте все вищезазначене потребує відповідного програмного та апаратного забезпечення, яке постійно оновлюється. Для того щоб підтримувати комп’ютери в належній формі, потрібно мати необхідне фінансування, адже нове програмне забезпечення (ПЗ) 3’являється буквально щодня і коштує немало. На жаль, школи не достатньо фінансуються державою, тому не мають змоги йти в ногу з часом.

Питанням теорії використання хмарних технологій у навчальному процесі досліджували такі науковці, як В. Биков, М. Жалдак, Л. Меджитова, 3. Сейдаметова, С. Семеріков, О. Спірін та ін. Проблемі використання хмарних обчислень для організації тестування присвячені розробки Н. Морзе, О. Кузьминської. Створенню освітніх ресурсів у середовищі Moodle на основі хмарної технології приділяють увагу у своїх роботах науковці I. Войтович та В. Сергієнко.

Метою статті $є$ розглянути перспективи використання хмарних технологій у ЗНЗ України.

На прикладі багатьох розвинених країн світу можна сказати, що розв’язанням цієї проблеми $є$ впровадження в навчальний процес так званих «хмарних технологій». «Хмарні технології - це технології, які надають користувачам Інтернету доступ до комп’ютерних ресурсів сервера і використання програмного забезпечення, як онлайн-сервіса» [3].

Такі новітні методи навчання спрямовані на вдосконалення навчального процесу, вони зможуть забезпечити учнів відповідним сучасним ПЗ, і школярі зможуть навчатися в темпі розвитку комп’ютерних технологій, що $\epsilon$ необхідною умовою інтеграції до європейського освітнього простору, при цьому із збереженням національних традицій в освіті України.

Щоб мати належну якість освіти, яка була б конкурентоспроможною у світі, ЗНЗ України повинні вдосконалювати навчальний процес, вносити в нього щось нове, та, головне, крокувати в ногу з часом.

Хмарні сервіси нині не використовуються в більшості шкіл України, проте їх упровадження стрімко зростає.

Наприклад, навчальні заклади нашої країни можуть вже зараз безкоштовно використовувати хмарні технології, які надає компанія Microsoft Україна. Для впровадження нових форм проведення уроку, зберігання даних та обміну ними, школи України можуть використовувати хмарний сервіс Office 365 [5]. Це є офісний пакет, який розміщений у «хмарі».

Такий хмарний офісний пакет є зручним у використанні, адже у його основі лежать пакети програм, які вчителі та учні звикли використовувати як у навчанні, так і в повсякденному житті. До складу цього пакету входить: 
- Microsoft Office Plus, який призначений для роботи з документами;

- Exchange Online, за допомогою якого можна використовувати сервіси електронної пошти Outlook, а також захищати комп’ютер від вірусів, використовувати календар та калькулятор;

- SharePoin, який служить для створення веб-сайтів та внутрішньої соціальної мережі;

- Lync Online, за допомогою якого можна створювати конференції між користувачами Office 365, обмінюватися миттєвими повідомленнями.

Office 365 має базовий тарифний план, який безкоштовний для всіх ЗНЗ України. Цим сервісом уже користуються багато українських шкіл та університетів (всього понад 237 тисяч облікових записів) [2].

Також увагу варто приділити такому хмарному сервісу, як Google Apps. Його використання в навчальному процесі надає безліч переваг, а також може забезпечити учнів необхідними додатками для роботи на уроках та самостійної роботи вдома. Серед них:

- Google Docs - oфic on-line;

- Google Maps - набір карт країн світу;

- Google Sites - безкоштовний хостинг;

- Google Translate - перекладач.

Перед тим як говорити про хмарні технології як звичне та постійне явище в навчальних закладах України, потрібно розглянути всі позитивні та негативні моменти впровадження їх в освіту.

Використання хмарних технологій має багато переваг. Надані сервіси є надійними, адже мають високу функціональність. У свою чергу, дані зберігаються у «хмарі», що значно заощаджує пам'ять комп’ютера, а обсяг дискового простору є великим. Доступ до даних, ресурсів і сервісів здійснюється індивідуально, користувач має змогу самостійно фільтрувати небажаний контент з боку системи, також робити це має змогу і адміністратор, а в навчальному процесі - учитель. Під час роботи в групах учні можуть об'єднуватися в підрозділи та групи користувачів за допомогою хмарних сервісів. Більшість хмарних сервісів мають підтримку україномовного інтерфейсу. Школи-користувачі можуть інтегрувати 3 іншими навчальними закладами, переймати досвід, обмінюватися даними в хмарі.

Як зазначалося вище, актуальною проблемою навчальних закладів є неможливість своєчасно оновлювати програмне та апаратне забезпечення, тож хмарні технології з легкістю її розв’язують (сервіси не мають проблем з оновленням програмного забезпечення, його нові версії завжди доступні). Незалежно від свого місцезнаходження, користувач завжди має доступ до свого робочого комп’ютера, корпоративних зв'язків та власних даних, щоб забезпечити це, варто мати лише мобільний пристрій та доступ до мережі Інтернет. Сервіс Google Apps найкраще працює з мобільними пристроями, які працюють на базі Google Android. Хмарні технології знаходяться у стані розвитку, тому і спектр пропонованих провайдером послуг постійно розширюється.

Незважаючи на безліч переваг використання хмарних сервісів, не слід забувати і про проблеми, які можуть виникнути в ході роботи 3 ними. Однією 3 таких є проблема компетентності вчителя в роботі з сервісом, нездатність доступно пояснити всі нюанси використання хмарних сервісів. Також не варто забувати про те, чи готові власне учні до використання хмарних технологій.

Варто акцентувати на тому, що використовувати хмарні технології можливо не лише на уроках інформатики, але й у процесі навчання інших предметів. Звичайно, учні 
використовують Інтернет для пошуку відомостей, підготовки до уроків, та це лише незначна частина тих можливостей, які може запропонувати мережа Інтернет.

У наш час вчителі пропонують школярам виконувати певні проекти та презентації $з$ різних дисциплін. Для цього вони зазвичай використовують пакет програм Microsoft Office, зокрема Power Point. Підготовка проектів завжди зацікавлює учнів, тому що вони мають можливість виявити свою ерудицію та фантазію.

Підготовка мультимедійної презентації допомагає добре засвоїти матеріал не лише глядачам, а й тому, хто готує її. Завдяки тому, що в такому вигляді дані представляються не лише текстом, а й мають багато малюнків, діаграм, анімацій (близько $70 \%$ графічних зображень), учням цікавіше працювати з таким матеріалом.

Існує багато редакторів та хмарних сервісів для підготовки мультимедійних презентацій, одним із них є хмарний сервіс Prezi [2]. Він надає змогу готувати захоплюючі проекти та презентації, зовнішній вигляд яких значно відрізняється від тих презентацій, які школярі звикли виконувати у Microsoft Power Point. Prezi розгортає безмежні можливості у створенні мультимедійних презентацій не лише для успішних менеджерів та аналітиків, але й для учнів загальноосвітніх навчальних закладів.

Досліджуючи роботу сервісу та придатність його до використання учнями, перше, на що варто звернути увагу - відсутність україномовного та наявність лише англомовного інтерфейсу. Багатьом здасться, що це великий недолік, проте якщо дивитися з іншого боку, то в цьому є велика перевага. Діти вивчають іноземну мову ще з початкових класів і більшість поглиблено, тож використання англомовного інтерфейсу лише вдосконалить знання англійської мови.

Розпочинати роботу в Prezi варто зі створення власного профілю, тобто робочого місця, у якому користувач зможе працювати і надалі. Під час реєстрації варто звернути увагу на пропозицію безкоштовного та платного користування, яке розкриває ширші можливості роботи над презентаціями. Виконані роботи зберігатимуться у хмарі, кожного разу, увійшовши в систему, користувач може переглядати власні презентації, вносити зміни у вже існуючі та додавати нові.

Користуватися цим сервісом досить зручно. Наприклад, готуючи презентацію на урок 3 географії, учень може використати таку тему, як карта світу. Весь матеріал можна представити у вигляді подорожі, долаючи відстань від країни до країни. Все це зображується стрілкоподібними зв’язками, нібито передаючи маршрут своєї подорожі (див. рис. 1). На місці певної країни можна вставити слайд і внести в нього будь-які відомості.

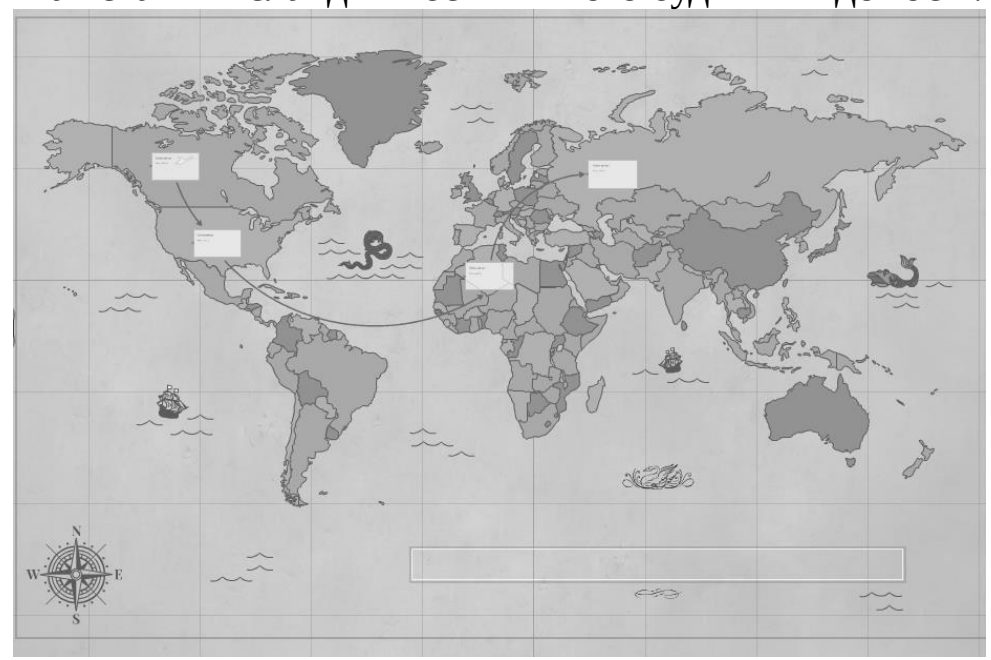

Рис. 1. Шаблон презентації «Карта світу» 
Організувавши структуру своєї презентації, варто приділити увагу їі оформленню. Сервіс пропонує багато можливостей для того, щоб урізноманітнити та наситити презентацію різними об’єктами. У розділі Insert, викликавши відповідний розділ меню, можна додати до презентації зображення, відео та музику, а також за допомогою цього меню можна вставляти стрілочки та лінії, які виконуватимуть роль зв'язків між слайдами (див. рис. 2).

Вибір розділу Symbols and Shapes падає можливість використати зображення, які пропонує сервіс Prezi. Зважаючи на те, що цей сервіс розглядається як допоміжний засіб для школярів, використовуючи який вони зможуть з легкістю готувати домашнє завдання у вигляді проектів та презентацій 3 різних шкільних дисциплін, то користуватись стандартними зображеннями сервісу буде завжди доречно завдяки їх різноманіттю (див. рис. 3).

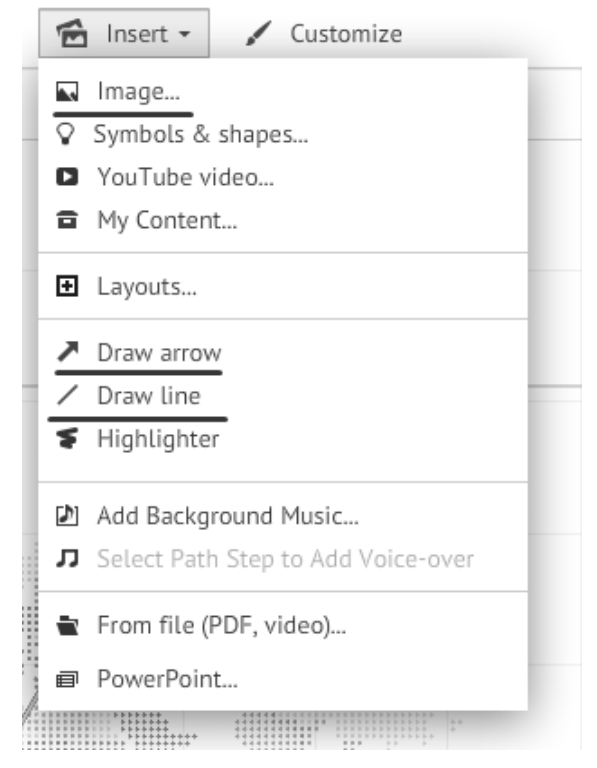

Рис. 2. Меню «Insert»

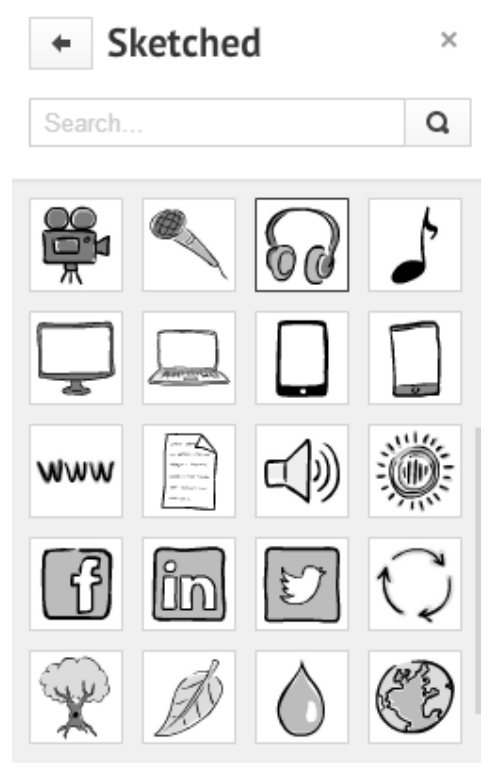

Рис. 3. Меню «Sketched»

Якщо жоден із шаблонів, фонів чи стандартних символів галереї Prezi не задовольняє ваших потреб, завжди можна використати власні зображення і додати їх до створюваної презентації. Презентувати роботу зможе кожен самостійно, перемикаючи слайди або встановивши час, з яким зображення змінюватимуться.

Отже, використання хмарних сервісів у школі має чималі перспективи розвитку. Учні матимуть змогу користуватися сучасними пристроями на уроках не лише інформатики, а й інших дисциплін, наприклад, географії, математики, біології чи хімії. Сервіс Prezi є яскравим прикладом того, як використання хмарних сервісів стає однією із новинок навчання у школі. Відверто кажучи, щось нове завжди приваблює, особливо школярів. Проте ті, хто не пам'ятає свого життя без пошукової системи Google чи соціальних мереж, не здивуються таким програмам, а з ентузіазмом візьмуться до їх освоєння. Основною метою використання хмарних сервісів $€$ створення умов для навчання, використовуючи всі можливості роботи у хмарі.

Надавши більших масштабів використанню хмарних сервісів у школі, вчителі та учні матимуть певні додаткові зручності, використання яких стане доречним у навчальному процесі, а з часом - звичною практикою для всіх ЗНЗ України.

\section{Література}

1. Вакалюк Т. А. Можливості використання хмарних технологій в освіті/ 
Т. А. Вакалюк // Актуальні питання сучасної педагогіки. Матеріали міжнародної науковопрактичної конференції (м. Острог, 1-2 листопада 2013 року). - Херсон : Видавничий дім «Гельветика», 2013. - С.97-99. 2. КМДА і Microsoft підписали угоду про впровадження інноваційних технологій [Електронний ресурс]. - Режим доступу : http:// economics.unian.ua/ transport/732520-kmda-i-microsoft-pidpisali-ugodu-pro-vprova djennya- innovatsiynihtehnologiy.html. - Назва 3 екрану. 3. Що таке хмарні обчислення або хмарні технології? [Електронний ресурс]. - Режим доступу: URL : http://programming. in.ua/otherfiles/internet/100-cloud-technologics.html. - Назва з екрану. 4. Vakaliuk T. Creating presentations for cloud services / Tetiana Vakaliuk// Journal L’Association 1901 «SEPIKE». - Osthofen, Deutschland. - Poitiers, France. - Los Angeles, USA. - Edition 05. - 2014. - P. 84-88. 5. Microsoft Office 365 [Електронний ресурс]. - Режим доступу: http://uk.wikipedia.org/wiki/ Microsoft_ Office_365. 6. Prezi [Електронний ресурс]. - Режим доступу : URL : http:// prezi.com/.

УДК 373.55.016:51(043.3)

Ніна Тарасенкова, Ірина Лов’янова

\section{ПОБУДОВА СИСТЕМИ ЗМІСТУ НАВЧАННЯ МАТЕМАТИКИ У ПРОФІЛЬНІЙ ШКОЛІ З ПОЗИЦІЙ ПРОФЕСІЙНОЇ СПРЯМОВАНОСТІ НАВЧАННЯ}

Тарасенкова Н. А., Лов’янова І. В. Побудова системи змісту навчання математики у профільній школі з позицій професійної спрямованості навчання.

У статті проаналізовано трактування поняття «зміст освіти», загальнотеоретичні підходи до структурування змісту шкільної освіти, вивчено принципи відбору змісту. На основі аналізу визначено фактори впливу на формування змісту шкільної математики і схарактеризовано компоненти змісту професійно спрямованого навчання математики.

Ключові слова: зміст освіти, принципи відбору змісту, компоненти змісту, професійно спрямоване навчання.

Тарасенкова Н. А., Ловьянова И. В. Построение системы содержания обучения математике в профильной школе с позиций профессиональной направленности обучения.

В статье проанализированы трактовки понятия «содержание образования», общетеоретические подходы к структурированию содержания школьного образования, изучены принципы отбора содержания. На основе анализа определены факторы влияния на формирование содержания школьной математики и охарактеризованы компоненты содержания профессионально направленного обучения математике.

Ключевые слова: содержание образования, принципы отбора содержания, компоненты содержания, профессионально направленное обучение.

Tarasenkova N. A., Lovyanova I. V. Formation of the teaching content of Mathematics at the profile school with professionally oriented training.

The article analyzes the meaning of the concept «content of education», theoretical approaches to structuring the content of school education and examins the principles of the content selection. On the basis of the analysis factors which influence the content formation of school Mathematics are defined and components of the content of professionally oriented training of Mathematics are characterized. 